\title{
Impact of Technologies During the COVID-19 Pandemic for Improving Behavioral Intention to Use E-Learning
}

\author{
Ragad M. Tawafak, Al Buraimi College, Oman \\ Sohail Iqbal Malik, Al Buraimi College, Oman \\ Ghaliya Alfarsi, Al Buraimi College, Oman
}

\begin{abstract}
This comprehensive study reviews the technological impact during the COVID-19 pandemic and elucidates technology usage to technology-enhanced learning which assisted in enhancing the behavioral intention to use technologies among undergraduates. Recently, higher education institutions suffered from the impact of using emerging technologies with electronic learning during the COVID-19 pandemic for improving student academic performance in a higher educational institution. The main purpose of this study is to determine the impact of technology-enhanced learning that allows the students to use emerging technologies and software to develop their skills and improve their academic performance. The method should influence critical instructions in the way of online learning through the COVID-19 pandemic. The results revealed that the unique features of TEL spur and encourage the behavioral intention to use e-learning. Additionally, social learning, perceived deterrents, and internal controls contribute to behaviors.
\end{abstract}

\section{KEYWORDS}

COVID-19, Higher Education Institutions, TEL

\section{INTRODUCTION}

The worldwide educations and universities have forced to fully converted to online teaching within the spreading of coronavirus COVID-19 pandemic. The converting in teaching from mostly traditional teaching to full online teaching has an unexpected situation of challenges (McKibbin \& Fernando, 2020). Universities faced a lot of economic problems that how to pay money to all staff, also, how to keep cleaning all places and facilities, equipment's used at campus (McKibbin \& Fernando,

\section{DOI: 10.4018/IJICTE.20210701.oa9}


2020)(Yousif \& Shaout, 2016). Higher education has a language that allows for increased funding for colleges and universities, depending on their achievements and approval from quality assurance (Fort, 2013). The main challenges were how to continue the research projects and offer programs to keep the same schedules and targets to be achieved within the same academic year, while they could easily dwarf to expanded to next year.

Undergraduate students or adults nowadays have been encircled with the guide of computerized innovation; their everyday lives and activities have additionally ended up entwined with online networking, mobile phones, tablets, and Internet use (Tawafak, 2018). Automated innovative expertise has fused to serve the current world situation with the spreading of corona-virus that started from China and spoiled into the whole world. Therefore, there was a severe need they make the most of every opportunity through the active use of e-learning. They have just begun to associate with computerized science for undergraduates, if now not even sooner, would be profoundly settled in what's more, firmly identified with advanced innovation in their own lives (Oman Academic Accreditation Authority, 2010; Porpiglia et al., 2020; Tawafak, Romli, Malik et al, 2019). To reach this point, each organization/ enterprise or universities need to address clear policies and how to implement emerging technologies within new standards. We hold various types of computerized divisions (Oman Academic Accreditation Authority, 2010). Will, in general, be fruitful in the public eye and affect the young age and its advanced future. Within this un-sufficient time of COVID-19 pandemic, the universities and international institutions still work on their approval of university standards (Tawafak, Romli, \& Arshah, 2019). Figure 1 shows the coronavirus around the world, and who the world effected with this new terrifying situation without previous preparations.

Figure 1. Coronavirus COVID-19 in Worldwise

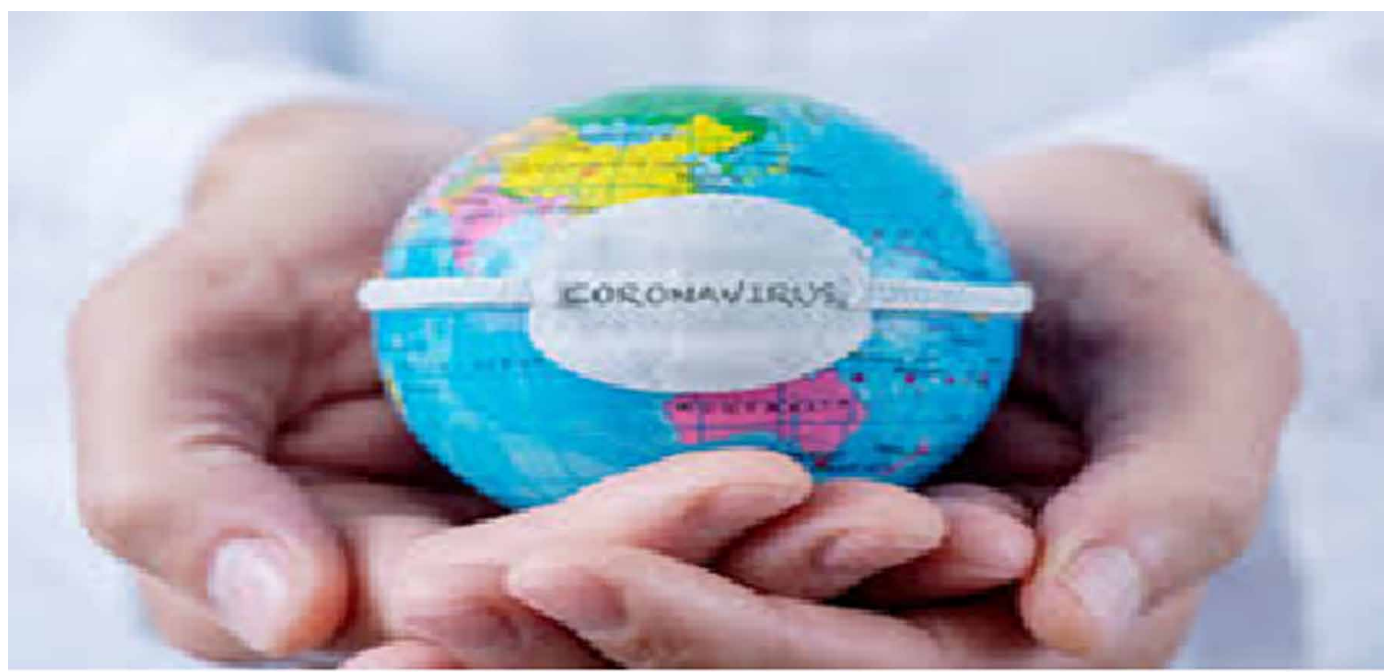

We keep up that the advanced separation is currently not just about computerized innovation introduction or use. Still, it deals with the new technology use and engagement for better behaviour intention. Anyway, this study focusses on showing a literature review on being in a situation to join advanced science into massive social exercises and benefitting from it (Zhu et al., 2020). The youthful innovation needs to take a hopeful and refined technique closer to mechanical design, for example, they should impartially investigate how it might and should be, and not take conveyance of how it is at present only. To do this, the more undergraduate wants to pick up abilities and intensity 
in advancing, structuring, programming, making, and building computerized science (Tawafak, Romli, \& Alsinani, 2019). Not exclusively are modifying fundamental, or Computational aptitudes and capacities comprising of those related to format and imagination.

At last, we recommend that we will motivate the undergraduates to make and structure computerized advances more prominent proactively, to be in smoothly use during the COVID-19 pandemic, and all the more, by and large, our computerized future. Be that as it may, universities are attempting to keep up with ongoing innovation developments. Furthermore, this combination of technology development and its usability should construct on the standards of access online of the application usage (Sandars et al., 2020).

Current resources and capacities, which incorporate factors, for example, innovation, culture, rehearses, relationship building abilities', and information as pleasantly as their qualities, perspectives, personalities, and attitudes, have been seen as limits to progressive change (Tawafak \& Awanis, 2018; Vial, 2019). In this get some answers concerning the computerized change started utilizing within the COVID-19 pandemic in preparing more undergraduate, the assortment of developing and achievable impediments that have been recommended (Azorín, 2020). Figure 2 tries to compromise the suitable suggestions for using online learning as a solution for this unexpected dangerous and unlimited duration of virus spreading.

Figure 2. Emerging technologies under COVID -19

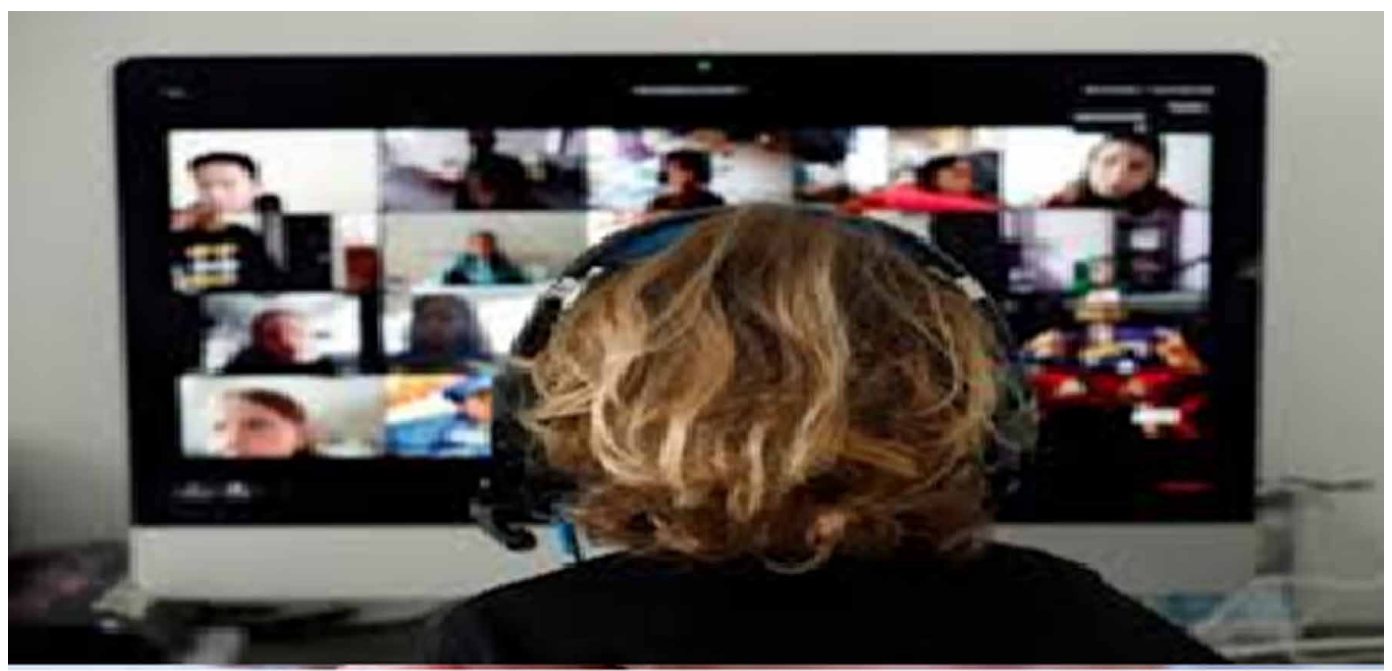

The study tries to comprehensive review to clarify the achievements of student learning by e-learning to overcome the coronavirus COVID-19 pandemic as a requirement for the university's standards and recommendations to be followed during the process (Porpiglia et al., 2020; Tawafak \& Mohammed, 2018; Wilby et al., 2017). What is the effect of many factors on the mechanism of updating curriculums, examination methods, and student feedback (Oman Academic Accreditation Authority, 2010; Tawafak \& Mohammed, 2018) within standards? The theoretical work consists of teaching and learning processes. This study tries to achieve the following objective: "To determine the most application used in blended learning applications that has many e-learning characteristics."

This study divided into several parts. First, related to research questions. Secondly, the innovation of solutions used by different countries and different viewpoints. Finally, the discussion and conclusions. 


\section{RESEARCH QUESTIONS}

How can the development of academic performance give accurate results by finding the relationship the e-learning system in the Covid-19 pandemic? Therefore, the study needs to take into account some factors such as college teaching tools, assessment methods, and student satisfaction with evaluation approval outcomes within learning process? This satisfaction did in cooperation with technology that enhances learning through the intention of student behaviour to use e-learning to improve outcomes (Tawafak, Romli, \& Arshah, 2019).

Figure 3 shows the impact and role of mass media and e-learning available with the COVID-19 pandemic overcomes. Figure 3 shows a variety of digital applications and a considerable number of platforms and system access.

\section{Figure 3. The impact and role of mass media with COVID-19 pandemic}

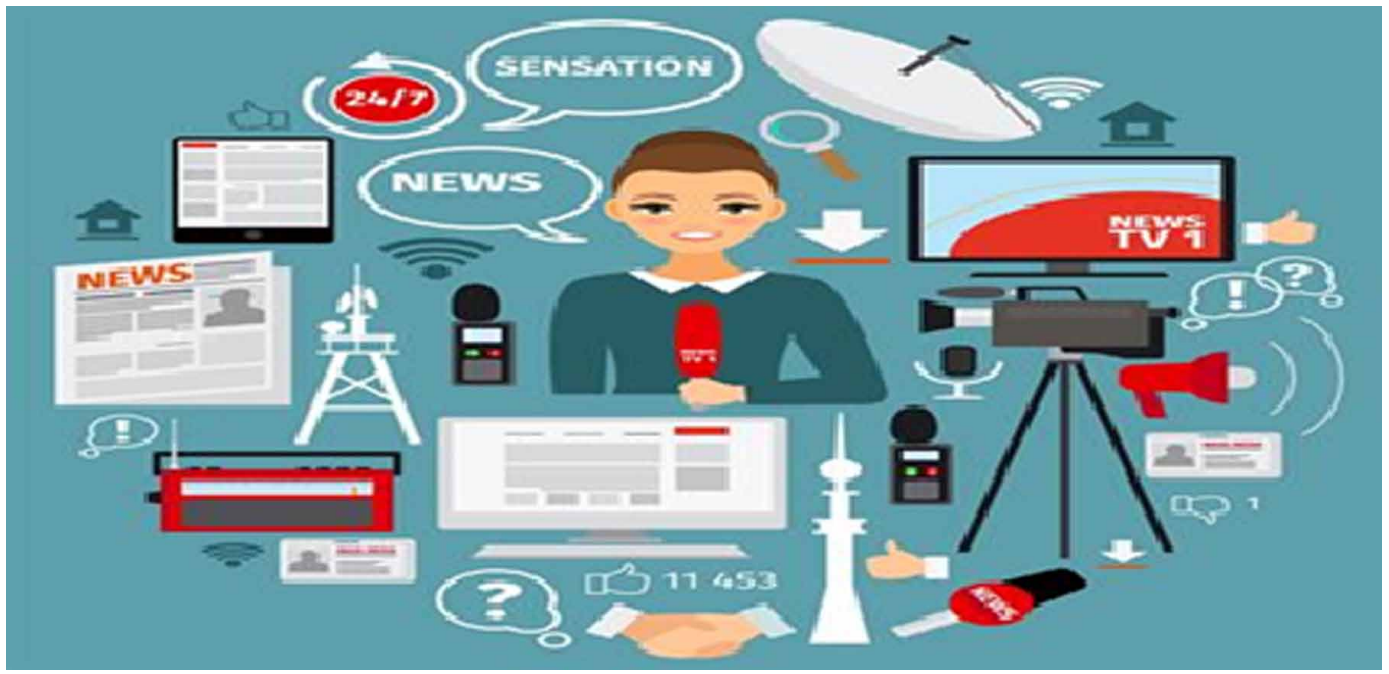

This research has some secondary research questions:

1. What is the existing applications and platforms applied in world educational institutions to handle the COVID-19 pandemic?

2. What is the suggestion of improvement to enhance student performance and behaviour intention to use e-learning models?

\section{LITERATURE REVIEW}

The computerized progress Especially inspires this study that the COVID-19 pandemic is calling for including youngsters and their essential instruction. The new advanced change depends entirely on the technologies and enhancement of using e-learning as a revolution for overcoming the COVID-19 pandemic. There are many determinant factors viable as a substitute irregular because these liable for essential training didn't incite or lead this stage deliberately, anyway instead just responded and looked to trade it urgently. To answer to the current situation. In any case, they depended intently on developing science to change their contributions and endeavoured to address and explore some fundamental and social alterations and restrictions nearby the way. 
A study presented by Tawafak et al. (2019) revealed in the last academic year that the Information Technology Department proposed a new strategy for using technologies in education by activating the use of Google classroom and uploading many recorded materials (Tawafak, Romli, Malik et al, 2019). Moreover, in this year of 2020, a new modification of the e-learning upgrade made by activating Moodle as a common platform. The student evaluation technology through Moodle was present in all facilities from the submission delay alarm, the reloaded files indicator, and the Excel files For all grades and tests online and using the URL to link the course with many exciting videos for further learning.

All universities and higher colleges were in the middle of semester two when the COVID-19 reached to the middle east. In the current situation of learning, the whole time changed to be an example in Oman, and daily class schedules remain as it is. The duration of each class has changed to compress from 30 to 45 minutes per lecture. The regulation here is to give recorded lectures for two weeks and upload them to Moodle for all students at the time of term, except for one semester, a live broadcast of the student's discussion and clarifications will make.

However, when the COVID-19 pandemic reached to the Middle East, all universities and higher colleges were in the middle of semester two of their academic year. The proposed action of the Ministry of Higher Education recommended that they consider some marks based on the results of the current course and the evaluations already made in each program. They initiate a supplementary procedure to continue the review with the remaining marks and the student support policy to improve their academic performance.

Besides, each institution has the responsibility to encourage the student to engage with e-learning and continuously test their behaviour intention with its impact on their academic performance. Table 1 pointed to time schedule in last semester.

Table 1. BUC adjusted solution of completing the academic year by adjusting classes

\begin{tabular}{|l|l|l|}
\hline \multicolumn{1}{|c|}{ Type } & \multicolumn{1}{|c|}{ Before as Traditional teaching } & \multicolumn{1}{c|}{ After COVID-19 as Online teaching } \\
\hline Duration Time & 3 hours per week & Limited time range (30-60 Minutes) per class \\
\hline Material & Textbooks, Handouts, Notes & Recorded slides and sharing links as textbook refereeing \\
\hline Attendance & $\begin{array}{l}\text { Physical attendance for both teachers } \\
\text { and students in classrooms }\end{array}$ & Internet access and joining live sessions if possible \\
\hline
\end{tabular}

Most Middle Eastern countries decided to follow the same rules and procedures. However, with this pandemic situation of COVID-19, the entire college has turned into fully online classrooms. Even college directors, college council, department committee, student affairs and all other departments in the college are doing their work and discussing the critical situation of learning challenges and students problem through Google Meet Technology, and all documents converted to electronic copies and pdf files are subject to ID, system or meeting sequence, for quality assurance as evidence On university standards (Mathew et al., 2019; Torous et al., 2020)

After all these steps suggested by the college administrators and the college council, the level of students joins and increases effectively to reach $98 \%$ of the total students in the college. Another challenge was how to take the exams and make sure all students would join simultaneously and take the exams ethically? For this reason, institutions decide the first semester to use online learning, not to take any test, and to replace all assessment tools to be in multiple assignments given to students as projects, case studies or mathematical questions with appropriate and sufficient time for student response and participation. 
Table 2. Middle East countries institution facilities

\begin{tabular}{|l|l|l|}
\hline & Before COVID-19 & After COVID-19 \\
\hline Equipment Devices & Time table schedule of regular lab use & Personal laptops donate for students. \\
\hline Online Services & Free access with college password & $\begin{array}{l}\text { Site labelled with .edu is free to } \\
\text { access by students. }\end{array}$ \\
\hline Accessibility & $\begin{array}{l}\text { Students access on the right time of } \\
\text { their class-schedules }\end{array}$ & Open source and free access \\
\hline
\end{tabular}

Most of the studies I submitted (Almarzooq et al., 2020; Chen \& Liu, 2020; Goh \& Sandars, 2020; Tawafak, n.d.; Tawafak, AlSideir, Alfarsi et al, 2019; Tawafak, Malik, \& Alfarsi, 2020) stated that the entire work well thought out about teaching methods, student satisfaction with new material for pre-recorded lectures with attached files from PowerPoint. Besides, Word copies of case studies, which they can watch during their spare time and guide them to solve their assignments. The aim of conducting live broadcast classes is to open a discussion between students and monitor their understanding, feedback, and acceptance of this new learning procedure. Also, for the hands-on courses, the learning has been completely transformed into a mixed-use between recording lectures and conducting the next class as a live broadcast to make sure all students understand the programming codes and have downloaded the correct version of the language translator. This technology also gives students the flexibility to watch video lectures remotely anytime it is free.

Likewise, the distinction in the instructions, and how to make the modified assignments for researchers at different levels, was an extra and tedious test. During online education, it has been not easy to form affirmative and far-reaching literary guides in promoting students who fulfil responsibilities at home with their mentor. In contrast to close and personal instruction, the trainer may need to not be present again for assistance, counselling when needed, and where required. In distant education, the educator must be fit to anticipate the difficulties that the researchers will face and how to overcome them (Tawafak, Romli, Abdullah et al, n.d.). Figure 4 shows that technology can help fight COVID-19.

Figure 4. Big tech contributing to help fight COVID-19

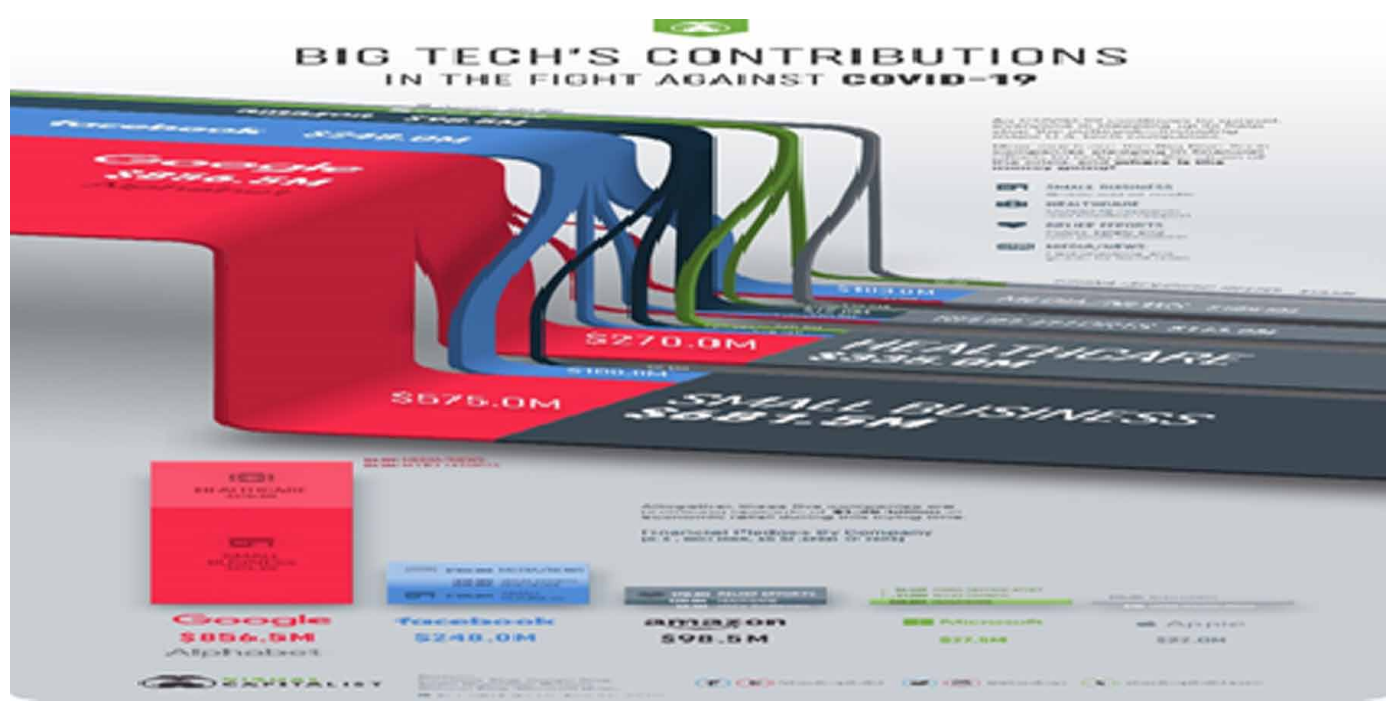


Table 3. Student learning flexibility

\begin{tabular}{|l|l|l|}
\hline & Before COVID-19 & After COVID-19 \\
\hline Participation & Five days per week & Free time to access and participate \\
\hline Teaching Method & $\begin{array}{l}\text { Private and individual } \\
\text { work }\end{array}$ & Peer-to-peer and teamwork allowed \\
\hline Assessment Tools & $\begin{array}{l}\text { Exam papers and projects } \\
\text { implementation }\end{array}$ & Uploaded assignment + online quizzes \\
\hline Plagiarism and Similarity & Not implemented & Less than 25\% \\
\hline
\end{tabular}

\section{INNOVATIVE SOLUTION}

In the second stage of students' perceptions, they begin to accept the situation and try to find a solution on how to switch to online learning. These changes in perceptions came because the ministry offered the new policy to help students by:

1. Free use of the Internet for all videos or materials with a .edu extension.

2. Free login time based on the quality and speed of the internet service. Therefore, students are free to join the Moodle platform at any time to watch the recorded lectures.

3. The evaluation process changed to become two evaluation tools with the option to encourage projects or reports on the presented topics without insisting on conducting live tests or compulsory attendance at specific times to evaluate tasks.

4. We are maintaining hotline calls to provide support to students who do not have high-quality personal computers for the phone, to be arranged by the college and the ministry to provide full support by donating devices for this type of economic situation.

5. Encourage students to work in teams and peer-to-peer support to overcome the course materials.

In the department of teachers and colleges, active work has been booming throughout overcoming the epidemic using the e-learning process (Tawafak, Malik, \& Alfarsi, 2020; Zhu et al., 2020). The students' tasks were adaptable and advanced options were used from several perspectives (Porpiglia et al., 2020; Zhu et al., 2020). The pandemic has given meetups for teachers you want to follow in the regular classroom to guide them later. One of them is the use of online frameworks for conducting tests (Tawafak, Romli, \& Arshah, 2019)—different online stages offer additional valuable spots for investigating and getting ready to test the results. Plus, for students on the move, the web provides unlimited assets for various topics. The teacher indicates that she will use these resources for future teaching as well. Since web-based training has been a triumph for a large number of students, the teacher may want to see the possibility of allowing extended it to experience it later (Almarzooq et al., 2020; Goh \& Sandars, 2020; Tawafak, AlSideir, Alfarsi et al, 2019; Tawafak, Malik, \& Alfarsi, 2020).

The instructors referred to the difficulties in going online inside days of the pandemic COVID-19. They needed to prepare new schedules for themselves, arrange cases with online meeting replacements, create weekly or bi-monthly exercise examine step-by-step or week-by-week (Tawafak, Romli, Abdullah et al, n.d.). Whatever the case, after the necessary work and getting used to it, the coaches have evolved to bring comfort with this new daily practice (Tawafak, Alfarsi, AlNuaimi et al, 2020).

The instructor was able to proceed with the work with the cell phone and tablets. One test the instructors confronted was at one time the absence of sources at the understudies' homes - cheat sheets, puzzles, developing squares, and many other challenges that need solutions.

There was once furthermore no real way to send and receive these things to the students at some phase in the lockdown as majority stores had shut and roads. Teachers have entrusted with concocting imaginative and dynamic arrangements. Generally speaking, the teachers who work with youths with 
uncommon necessities, and educators, by and large, are showing flexibility and persistence, with regards to the acing and prosperity undergrads. The most significant weight they felt objectified to be large abandoned (Chick, Clifton, Peace et al, 2020; Chick, Peace, \& Kemp Bohan, 2020; Wang et al., 2020).

Figure 5 shows the university and quality assurance steps to solve teaching requirements and stages to get acceptance and approval with student behavior.

Figure 5. Stages of evaluating behavior intention

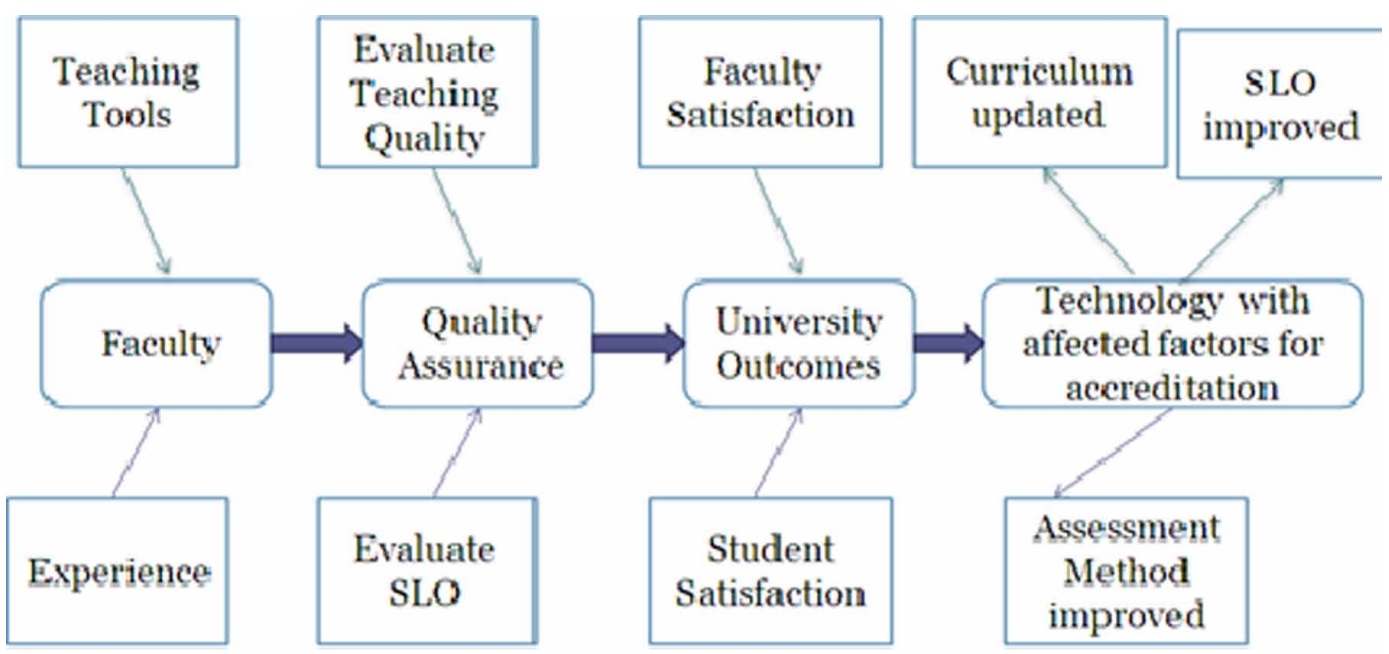

\section{RESULTS AND IMPACT}

Having known the behaviour intention be an essential part of the e-learning. The challenges of supervising and control the management within the IT groups have dealt with auditors for the whole process. The study illustrates the IT framework to outfit the use of communication tools that include a massive use of emails and the most usable free application software such as Monkey survey and Google applications available in emails. Such type of applications grouped under the general name of technology-enhanced learning (TEL) techniques; used for specific control purposes They also give the least benefit in idea control, but their supports for control security and authentication protection objectives increases as more complexities and challenges emerge. Also, the method tries to keep up the advanced separation among students because of COVID-19 pandemic, is currently not just about computerized innovation introduction or use, anyway about being in a situation to join advanced science into massive social exercises and benefitting from it (Chen \& Liu, 2020; Goh \& Sandars, 2020; Tawafak, n.d.; Tawafak, Malik, \& Alfarsi, 2020; Zhu et al., 2020).

The method of innovation solution technique is a link between university assessment standards and decision-makers to full use of the e-learning system. The method stands on three main decisionmakers. First, the university requirement standard to help in developing its approval process. The development based on behaviour intention to use e-learning system standards. Second, how much the percentage accuracy ratio could affect each available application which the enhanced algorithm suggested for students and TEL usage as e-learning ways. Third, the Moodle platform used to test the results to approve the effect of technology services in improving academic performance in terms of faculty and student satisfaction, and technology improvement and university outcomes. This 
Figure 6. Expected impacts of COVID-19 in education sectors

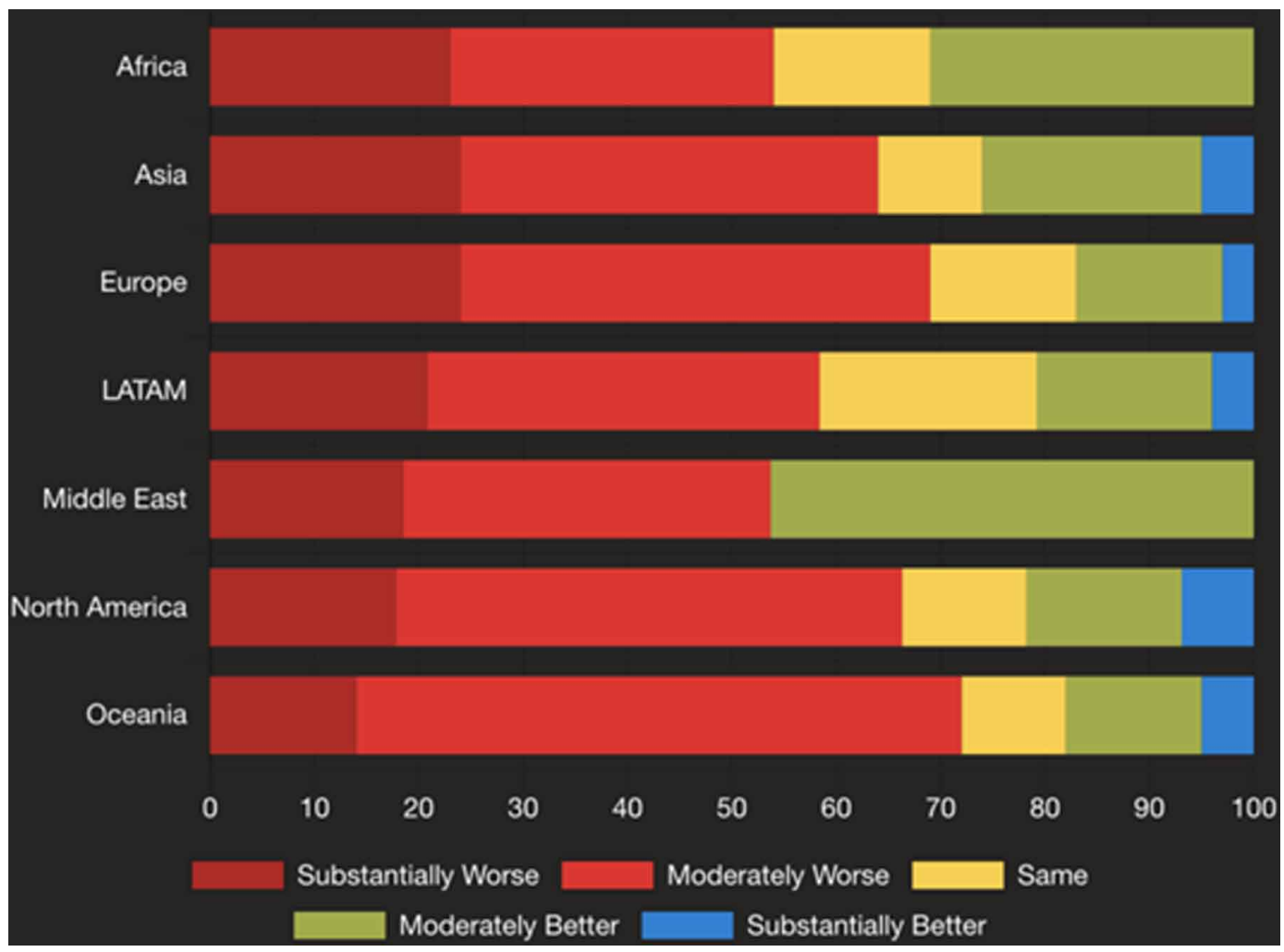

point could implement by proposing a computational model of web-based survey research which is accepted for researching some populations connected between features and TEL usability (Figure 6).

1. Written Outcomes: This includes course goals, program outcomes, course objectives, and suggested elective and equalization courses. The method supports the use of related terms matched with e-learning courses. It should offer e-learning courses matching with regular curriculum (Tatnall, 2020).

2. Student Learning Outcomes (Assessment Procedure): This standard is achieved by first determining whether the student skills accepted with his primary degree in the university or not. Secondly, if each course outcomes approved on the electronic portal system and the existence of a stamped hard copy report for each course result and achievement (Tatnall, 2019).

3. Teaching Quality (Experience, and Techniques): This standard includes two phases-first, the faculty experience and familiarity with the course material and required applications. Secondly, the level of understanding to TEL used for improving different applications like Wiki chat, YouTube software, Google applications, video programs, etc. that help and develop course descriptions and objectives.

\section{FINDINGS}

Transparency has identified as an essential requirement for communication skills (Alfarsi et al., 2019; Eldow et al., 2006; Park et al., 2020; Tawafak, Buraimi, Jabbar et al, n.d.). 
1. In video-based applications, the weakness is the time for the extra work of audio files that are recorded and assigned by the class blogs.

2. One-to-one chatting recommended for students who are shy to ask questions or have a mistake on the initial idea. Therefore, it is the reason for having a private chat room.

3. Create an online peer moderator video blog for a group of participants.

4. Add a translated method to convert student voices into written text. This method will make reading more accessible and reduce writing time and grammar effort. It also solves the problem of applied pedagogy. This translator will make it easier to understand and arrange comments for scientific answers.

5. The new model design based on two types of work - first, the use of single reports and assignments for each student to measure their understanding. Second is the use of group mates on the topic or preference of students to evaluate the attached essays and projects. The two report results will be reviewed by different faculties to ensure that the mixture of techniques will develop the course objectives.

6. Add an external auditor who will be responsible for approving teaching materials, assessment methods, and be sure of fitting with the course objectives. Engage more than two faculties for preparing course material. Each one will assess the individual assignments and reports and the practical applications attached for each student to improve students' grades further and to check their understanding of each evaluation.

\section{CONCLUSION AND RECOMMENDATIONS}

This study examined a student his/her behaviour intention to use the e-learning system as an alternative option for fighting the COVID-19 pandemic. An institution chosen to conduct the research, and AlBuraimi College as a private university was selected to analyze the procedure of teaching and learning for BUC students. In conclusion, this study investigates the unprecedented circumstance with the current state of teaching and learning in both schools and higher educational institutions, will change the way of learning from traditional teaching method to fully online learning method. The study also illustrates the challenges phased the learning process in each stage and each country differently based on the level of commencement of flexibility and usability of internet use and acceptance to move towards online learning, without knowing if this situation will end after months or after a long time. This study tries to innovate and cooperate with the scientific fields such as business, information technology, engineering, law, and social studies and be leaders in life and national societies to maintain the standards of teaching and learning for an easy process and stable movement to get the means of universities.

\section{ACKNOWLEDGMENT}

The authors want to thank all journals for allowing us to publish our achievements. 


\section{REFERENCES}

Al Farsi, G., Jabbar, J., Tawafak, R. M., Malik, S. I., Alsidiri, A., \& Alsinani, M. (2020). Mobile Application System Supported BUC Students Services and Learning. International Journal of Interactive Mobile Technologies, 14(9).

Alfarsi, G., Sulaiman, H., Tawafak, R. M., Malik, S., Jabbar, J., \& Alsidiri, A. (2019). A Study of Learning Management System with E-Learning. Academic Press.

Almarzooq, Z., Lopes, M., \& Kochar, A. (2020). Virtual learning during the COVID-19 pandemic: a disruptive technology in graduate medical education. Academic Press.

Azorín, C. (2020). Beyond COVID-19 supernova. Is another education coming? Journal of Professional Capital and Community, 5(3/4), 381-390. doi:10.1108/JPCC-05-2020-0019

Bittner, J. G. T. IV, Logghe, H. J., Kane, E. D., Goldberg, R. F., Alseidi, A., Aggarwal, R., \& Jacob, B. P. (2019). A Society of Gastrointestinal and Endoscopic Surgeons (SAGES) statement on closed social media (Face-book(R)) groups for clinical education and consultation: Issues of informed consent, patient privacy, and surgeon protection. Surgical Endoscopy, 33(1), 1-7. doi:10.1007/s00464-018-6569-2 PMID:30421077

Chen, L. T., \& Liu, L. (2020). Social Presence in Multidimensional Online Discussion: The Roles of Group Size and Requirements for Discussions. Computers in the Schools, 1-25.

Chick, R. C., Clifton, G. T., Peace, K. M., Propper, B. W., Hale, D. F., Alseidi, A. A., \& Vreeland, T. J. (2020). Using technology to maintain the education of residents during the COVID-19 pandemic. Journal of Surgical Education, 77(4), 729-732. doi:10.1016/j.jsurg.2020.03.018 PMID:32253133

Chick, R. C., Peace, K. M., \& Kemp Bohan, P. M. (2020). Trainee Perception and Efficacy of a Flipped Classroom Model in General Surgery Academic Conferences, 2020. Association for Surgical Education.

Clustering, A. S. (2019). International Arab Conference on Information Technology (ACIT). Higher Education, 165,170 .

Eldow, Shakir, Talab, Muttar, \& Tawafak. (2006). Literature review of authentication layer for public cloud computing: A meta-analysis. Academic Press.

Fort, E. (2013). Survival of the historically Black colleges and universities: Making it happen. Lexington Books.

Goh, P. S., \& Sandars, J. (2020). A vision of the use of technology in medical education after the COVID-19 pandemic. MedEdPublish, 9(1), 9. doi:10.15694/mep.2020.000049.1

Huang, R. H., Liu, D. J., Tlili, A., Yang, J. F., \& Wang, H. H. (2020). Handbook on facilitating flexible learning during educational disruption: The Chinese experience in maintaining undisrupted learning in COVID-19 Outbreak. Smart Learning Institute of Beijing Normal University.

Iivari, N., Sharma, S., \& Ventä-Olkkonen, L. (2020). Digital transformation of everyday life-How COVID-19 pandemic transformed the basic education of the young generation and why information management research should care? International Journal of Information Management, 55, 102183. doi:10.1016/j.jinfomgt.2020.102183 PMID:32836640

Iyer, P., Aziz, K., \& Ojcius, D. M. (2020). Impact of COVID-19 on dental education in the United States. Journal of Dental Education, 84(6), 718-722. doi:10.1002/jdd.12163 PMID:32342516

Jabbar, J., Malik, S. I., AlFarsi, G., \& Tawafak, R. M. The Impact of WhatsApp on Employees in Higher Education. In Recent Advances in Intelligent Systems and Smart Applications (pp. 639-651). Springer. doi:10.1007/9783-030-47411-9_34

Malik, S., Al-Emran, M., Mathew, R., Tawafak, R., \& AlFarsi, G. (2020). Comparison of E-Learning, M-Learning and Game-based Learning in Programming Education-A Gendered Analysis. International Journal of Emerging Technologies in Learning, 15(15), 133-146. doi:10.3991/ijet.v15i15.14503

Mathew, R., Malik, S. I., \& Tawafak, R. M. (2019). Teaching Problem Solving Skills using an Educational Game in a Computer Programming Course. Informatics in Education, 18(2), 359-373. doi:10.15388/infedu.2019.17 
McKibbin, W. J., \& Fernando, R. (2020). The global macroeconomic impacts of COVID-19: Seven scenarios. Academic Press.

Oman Academic Accreditation Authority. (2010). Retrieved 1 1, 2010, from www.oaaa Oman: http://www. oaaa.gov.om/ar/Default.aspx

Park, S., Choi, G. J., \& Ko, H. (2020). Information technology-based tracing strategy in response to COVID-19 in South Korea-Privacy controversies. Journal of the American Medical Association, 323(21), 2129. doi:10.1001/ jama.2020.6602 PMID:32324202

Porpiglia, F., Checcucci, E., Amparore, D., Verri, P., Campi, R., Claps, F., \& Mario Scarpa, R. et al. (2020). Slowdown of urology residents' learning curve during the COVID-19 emergency. BJU International, 125(6), E15-E17. doi:10.1111/bju.15076 PMID:32274879

Sandars, J., Correia, R., Dankbaar, M., de Jong, P., Goh, P. S., Hege, I., \& Webb, A. et al. (2020). Twelve tips for rapidly migrating to online learning during the COVID-19 pandemic. MedEdPublish, 3068.

Tatnall, A. (2019). Editorial for EAIT issue 2, 2019. Education and Information Technologies, 24(2), 953-962. doi:10.1007/s10639-019-09874-7

Tatnall, A. (2020). Editorial for EAIT issue 2, 2020. Education and Information Technologies, 25(2), 647-657. doi:10.1007/s10639-020-10135-1

Tawafak, F. R. M. (n.d.). The comprehension theories of continuous intention to use TEL with e-learning models in educations. Academic Press.

Tawafak, R., Romli, A., Malik, S., \& Shakir, M. (2020). IT Governance Impact on Academic Performance Development. International Journal of Emerging Technologies in Learning, 15(18), 73-85. doi:10.3991/ijet. v15i18.15367

Tawafak, R. M. (2018). Assessing the impact of technology learning and assessment method on academic performance. Eurasia Journal of Mathematics, Science and Technology Education, 14(6), 2241-2254. doi:10.29333/ejmste/87117

Tawafak, R. M., Alfarsi, G., AlNuaimi, M. N., Eldow, A., Malik, S. I., \& Shakir, M. (2020, April). Model of Faculty Experience in E-Learning Student Satisfaction. In 2020 International Conference on Computer Science and Software Engineering (CSASE) (pp. 83-87). IEEE. doi:10.1109/CSASE48920.2020.9142071

Tawafak, R. M., AlSideir, A., Alfarsi, G., Al-Nuaimi, M. N., Malik, S. I., \& Jabbar, J. (2019). E-learning Vs. Traditional Learning for Learners Satisfaction. E-learning, 29(3), 388-397.

Tawafak, R. M., \& Awanis, B. T. (2018). Continued Intention to use UCOM: Four factors for integrating with a technology acceptance model to moderate the Satisfaction of Learning. IEEE Access : Practical Innovations, Open Solutions, 6, 66481-66498. doi:10.1109/ACCESS.2018.2877760

Tawafak, R. M., Buraimi, O., Jabbar, J., Alfarsi, G., Malik, S. I., Romli, A., \& Alsideiri, A. (n.d.). A Review Paper on Student-Graduate Advisory Expert system. Academic Press.

Tawafak, R. M., Malik, S. I., \& Alfarsi, G. (2020). Development of Framework from Adapted TAM with MOOC Platform for Continuity Intention. Development, 29(1), 1681-1691.

Tawafak, R. M., \& Mohammed, M. N. (2018). Review on the effect of student learning outcome and teaching Technology in Omani's higher education Institution's academic accreditation process. Proceedings of the 2018 7th International Conference on Software and Computer Applications, 243-247. doi:10.1145/3185089.3185108

Tawafak, R. M., Romli, A., \& Arshah, R. A. (2019, August). E-learning prospect on improving academic performance in Omani Universities. IOP Conference Series. Materials Science and Engineering, 551(1), 012033. doi:10.1088/1757-899X/551/1/012033

Tawafak, R. M., Romli, A., Malik, S. I., Shakir, M., \& Alfarsi, G. M. (2019). A systematic review of personalized learning: Comparison between E-learning and learning by coursework program in Oman. International Journal of Emerging Technologies in Learning, 14(09), 93-104. doi:10.3991/ijet.v14i09.10421

Tawafak, R. M., Romli, A. B., Abdullah, R., Alfarsi, G., Jabbar, J., Esbai, R., ... Abdelhameed, W. (n.d.). Competitiveness \& Quality. Academic Press. 
Tawafak, R. M., Romli, A. B., Arshah, R. A., \& Malik, S. I. (2020). Framework design of university communication model (UCOM) to enhance continuous intentions in teaching and e-learning process. Education and Information Technologies, 25(2), 817-843. doi:10.1007/s10639-019-09984-2

Tawafak, R. M., Romli, A. B., \& Arshah, R. B. A. (2019, February). E-learning Model for Students' Satisfaction in Higher Education Universities. In 2019 International Conference on Fourth Industrial Revolution (ICFIR) (pp. 1-6). IEEE. doi:10.1109/ICFIR.2019.8894778

Tawafak, R. M., Romli, A. M., \& Alsinani, M. J. (2019). Student Assessment Feedback Effectiveness Model for Enhancing Teaching Method and Developing Academic Performance. International Journal of Information and Communication Technology Education, 15(3), 75-88. doi:10.4018/IJICTE.2019070106

Teräs, M., Suoranta, J., Teräs, H., \& Curcher, M. (2020). Post-Covid-19 Education and Education Technology 'Solutionism': A Seller's Market. Postdigital Science and Education, 1-16.

Tian, S., Hu, N., Lou, J., Chen, K., Kang, X., Xiang, Z., \& Chen, G. et al. (2020). Characteristics of COVID-19 infection in Beijing. The Journal of Infection, 80(4), 401-406. doi:10.1016/j.jinf.2020.02.018 PMID:32112886

Ting, D. S. W., Carin, L., Dzau, V., \& Wong, T. Y. (2020). Digital technology and COVID-19. Nature Medicine, 26(4), 459-461. doi:10.1038/s41591-020-0824-5 PMID:32284618

Torous, J., Myrick, K. J., Rauseo-Ricupero, N., \& Firth, J. (2020). Digital mental health and COVID-19: Using technology today to accelerate the curve on access and quality tomorrow. JMIR Mental Health, 7(3), e18848. doi:10.2196/18848 PMID:32213476

Vial, G. (2019). Understanding digital transformation: A review and a research agenda. The Journal of Strategic Information Systems, 28(2), 118-144. doi:10.1016/j.jsis.2019.01.003

Wang, C. J., Ng, C. Y., \& Brook, R. H. (2020). Response to COVID-19 in Taiwan: Big data analytics, new technology, and proactive testing. Journal of the American Medical Association, 323(14), 1341-1342. doi:10.1001/jama.2020.3151 PMID:32125371

Wilby, K. J., Zolezzi, M., \& El-Kadi, A. (2017). Development of a college-level assessment framework in line with international accreditation standards: A Middle Eastern perspective. Currents in Pharmacy Teaching \& Learning, 9(1), 115-120. doi:10.1016/j.cptl.2016.08.028 PMID:29180143

Yousif, M. K., \& Shaout, A. (2016). Fuzzy logic computational model for performance evaluation of Sudanese Universities and academic staff. Journal of King Saud University - Computer and Information Sciences.

Zhu, N., Zhang, D., Wang, W., Li, X., Yang, B., Song, J., ... Niu, P. (2020). A novel coronavirus from patients with pneumonia in China, 2019. New England Journal of Medicine. 
Ragad M. Tawafak is a PhD student in Computer Science at Universiti Malaysia Pahang. She got her MSc in Computer Science from AIMousel University in Iraq about hybrid neural network and genetic algorithms. Tawafak got her Bachelor degree from AIMousel University with an expert system of bacteria classification project.

Sohail lqbal Malik got the fifth honour degree in Computer Science. She worked in Software engineering department in AlMustansryia University in Iraq for four years. She worked in Oman College of Management and Technology for two years. Currently, she is a lecturer in information technology department in ALBuraimi College, Oman more than twelve years. Most of her publications were indexed under Scopus. Her current research interests include e-learning, Technology Adoption \& Acceptance, Academic performance. Sohail lqbal Malik's research interest includes Algorithmic Thinking, Computer Education, Technology in Education, Problem Solving Skills and Mobile Learning.

Ghaliya AIFarsi got her Master degree in computer science at the University of Sohar in Oman (2015), and Bachelor of Science degree in Computer Science at Ajman University, AIAin, UAE (2004). she is a lecturer in information technology department in AlBuraimi College, Oman more than twelve years. Most of her publications were indexed under Scopus. her research expertise are in knowledge management, integrated system, e-learning, m-learning and image processing. And published in international journals. 